\title{
Screening of Bacteria for Biosurfactants, Exopolysaccharides and Biofilms and their Impact on Growth Stimulation of Zea mays Grown under Petrol Stress
}

\author{
Sabiha Habib and Ambreen Ahmed* \\ Institute of Botany, University of the Punjab, Quaid-e-Azam Campus, Lahore 54590, Pakistan \\ *For correspondence: ambreenahmed1 @ hotmail.com \\ Received 04 February 2021; Accepted 27 April 2021; Published 10 July 2021
}

\begin{abstract}
Environmental stress imposed by petroleum hydrocarbons can compensate by use of auxin-producing bacteria having potential for biosurfactants production, to assist improved plants' growth in petrol contaminated areas. In the present work, four auxin-producing bacteria were screened for biosurfactants, exopolysaccharides (EPS) and biofilms production capability. We hypothesized that Enterobacter sp. (A5C) was the most efficient strain with respect to biosurfactant production and can accumulate EPS as well as biofilms. This strain was attributed to exhibit emulsification index, percentage of hydrophobicity and percentage of hydrocarbon degradation more than 50\%. Also, it produced $9.27 \mathrm{mg}$ of EPS per $100 \mathrm{~mL}$ of culture while Fourier transform infrared spectroscopy (FTIR) confirmed the presence of alcoholic and carboxylic groups, ketone and sugars in it. Results of in vitro plant microbe interaction assay revealed its potential to stimulate the growth of Zea mays L. plants under 1 and $2 \%$ of petrol stress by improving physio-chemical attributes of treated plants, over control. Thus, it is concluded that the test organism i.e., Enterobacter sp. (A5C) might be involved in developing bacterial community (EPS and biofilms) that helped to colonize the bacteria to the plant roots and soil particles that ultimately encouraged the more access to nutrients and protection of plant roots from toxins in soil ecosystem. (C) 2021 Friends Science Publishers
\end{abstract}

Keywords: Enterobacter sp.; Exopolysaccharides; FTIR; Biofilm; Zea mays

\section{Introduction}

Worldwide increasing hydrocarbons and petrol pollution in soil ecosystem reduces the potentiality of plants to grow in petrol contaminated areas. Inadvertent release of petroleum products and leakage of petroleum hydrocarbons from oil spills causing damage to soil and ultimate retardation in cultivation of crop plants in such areas. To meet this challenge, synthetic approaches are being used but they are causing severe threat to the environment. Thus, the usage of biosurfactants is considered as effective way to reduce hydrocarbons contamination from soil ecosystem (Joy et al. 2017). It has been reported that petroleum hydrocarbons are deemed as serious environmental threat not only for soil community but plant community as well. Owing to the sessile nature of plants, to escape out from such stresses is not possible for plants. Traditional and synthetic means for remediation of petroleum pollutants from soil ecosystem are ecologically damaging, thus, use of biological approaches i.e., microbes can compensate this issue (Gull et al. 2019; Xia et al. 2020).

According to Pendse and Aruna (2018), bacteria are reported as biosurfactant and bioemulsifier producers and considered as natural tool to remediate petrol contamination. Biosurfactants are bacterial metabolites that have both hydrophobic and hydrophilic domains and tend to accumulate at the interface of hydrocarbons (HC). They can tremendously decrease the surface tension and interfacial tension of growing media. These biosurfactants may contain fatty acids, lipopeptides, lipids, polysaccharides, proteins and some other compounds having amino, phosphate and carboxyl groups (Nishanthi et al. 2010; Joy et al. 2017).

On the other side, bacteria produce extracellular components along with biosurfactants i.e., plant growth promoting agents, exopolysaccharides (EPS) and biofilms. Bacterial EPS are considered as biomolecules secreted by bacteria having diverse functions like environmental safety, adherence to biotic or abiotic surfaces and cellular interactions (Escárcega-González et al. 2018). Bacterial colonization either with biotic surfaces or abiotic materials provide them several survival strategies like improved access to nutrients, preservation of extracellular enzymatic activities and protection from toxins etc. EPS play an important role in the attachment of bacteria to different substrates that ultimately make biofilms. These extracellular EPS can be used as gelling and thickening agents, flocculants, stabilizers, 
adhesives and emulsifying agents (Kumar et al. 2011). According to Kurmusaoğlu (2019), EPS help attach the bacteria to biotic or abiotic surfaces and after attachment, bacteria are getting aggregated via cell to cell adhesion and this aggregation continues till the biofilms become mature.

The present study was aimed at screening of auxin producing rhizospheric bacteria for the production of biosurfactants, EPS and biofilms. The best strain was further used to assess its potential for growth stimulation in maize (Zea mays L.) plants after bacterial inoculation under petrol stress.

\section{Materials and Methods}

\section{Bacterial cultural conditions}

The present work dealt with the evaluation of bacterial attributes i.e., biosurfactant production potential, EPS and biofilm production. For this purpose, four already isolated and identified rhizospheric bacterial strains were used, which were previously reported for auxin production i.e., $[\mathrm{A} 5 \mathrm{C}=$ Enterobacter sp. $(\mathrm{HQ179967})], \quad[\mathrm{A} 9 \mathrm{G}=$ Enterobacter cloacae (HQ202888)], A11E [Enterobacter sp. (HQ533177)] and A13G (Exiguobacterium sp. (HQ202890)] (Ahmed and Hasnain 2020). Isolates were maintained on LB-agar media by incubating at $37^{\circ} \mathrm{C}$ for 24 $\mathrm{h}$ and further screened for biosurfactants production, EPS and biofilm synthesis.

\section{Bacterial profiling for biosurfactant production potential}

Isolates were observed for biosurfactant production potentiality via emulsification index test, bacterial adhesion to hydrocarbons (BATH) assay, penetration assay, hydrocarbon overlay agar method and hydrocarbon (HC) degradation assay. The $n$-hexane was used as $\mathrm{HC}$ for all assays.

Emulsification index test was done following Shoeb et $a l$. (2015). For this, cell-free broth $(1.5 \mathrm{~mL})$ was mixed with equal amount of HC, vortexed for two min and then allowed to stand for $24 \mathrm{~h}$ for developing emulsion layer. Emulsification index $\left(\mathrm{E}_{24}\right)$ was determined following the equation: $E_{24}=$ Emulsion layer height/total height of solution $\times 100$.

BATH assay was performed following the method of Thavasi et al. (2011). Bacterial cell pellets were washed with sterilized water and resuspended in $25 \mathrm{mM}$ phosphate buffer and diluted to OD $\sim 0.5$ at $600 \mathrm{~nm}$ with the same buffer. After that, $2 \mathrm{~mL}$ of cells were mixed with $100 \mu \mathrm{L}$ of $\mathrm{HC}$, vortexed for $3 \mathrm{~min}$ and allowed to stand for one $\mathrm{h}$. Decrease in absorbance was recorded to calculate the percentage of cells adherence to $\mathrm{HC}$ using the following formula:

Percentage adherence to $\mathrm{HC}=1-\left(\mathrm{OD}_{\text {aqueous phase }} / \mathrm{OD}_{\text {initial cell suspension }}\right) \times 100$.

Penetration assay was done following Walter et al. (2010).
For this assay, hydrophilic phase was prepared by mixing same amount of cell-free bacterial supernatant and red staining solution while hydrophobic paste was prepared by mixing silica gel in $\mathrm{HC}(1 \mathrm{~mL})$. Reaction mixture was primed by adding hydrophilic and hydrophobic mixtures in test tubes separated by $100 \mu \mathrm{L}$ of HC. Results were recorded after fifteen min by observing the color change.

Hydrocarbon overlay agar method was done following Shoeb et al. (2015). For which, bacterial spot inoculation was done on $\mathrm{HC}$ coated L-agar plates and appearance of halo areas were observed qualitatively after $48 \mathrm{~h}$ of incubation. $\mathrm{HC}$ degradation assay was performed following 2, 6dichlorophenol indophenol (DCPIP) method using 1 and $2 \%$ of $\mathrm{HC}$ as sole carbon source following Habib et al. (2017).

\section{Bacterial profiling for EPS detection}

Bacterial EPS biosynthesis was examined following Welman and Maddox (2003) and Mu'minah et al. (2015) via mucoidy, ropiness and acetoin production assays qualitatively. Bacteria were grown using the growth media ATCC no. 14 and colonies forming thick slime (mucoid) were noted. Bacterial ropiness was observed using inoculation loop while acetoin production was checked via Voges-proskauer test. Quantitatively, bacteria were grown in $100 \mathrm{~mL}$ nutrient agar media amended with sucrose as carbon source and incubated for three days. Cells were harvested via centrifugation for $20 \mathrm{~min}$ at $10,000 \mathrm{rpm}$ and then twofold isopropanol was added into it following incubating at $4^{\circ} \mathrm{C}$ overnight. Precipitates were then collected by centrifugation and pellets were dried at $100^{\circ} \mathrm{C}$. Weight of dried EPS was recorded. Fourier transform infrared spectroscopy (FTIR) was done for extracted EPS and IR spectra were obtained in the range of 650 to $4000 \mathrm{~cm}^{-1}$ of absorption using 32 scans.

\section{Bacterial profiling for biofilm production}

For bacterial biofilm assessment, isolates were inoculated in liquid Bushnell Haas (BH) minimal media supplemented with $0.2 \%$ dextrose and $0.5 \%$ tyrptone and after $72 \mathrm{~h}$ of incubation, cultures were discarded and $1 \%$ crystal violet solution was poured in the test tubes for staining purpose. After 15 to $20 \mathrm{~min}$, excess stain was washed out and biomass of attached bacterial cells (biofilm) was quantified by solubilization of dye in $2 \mathrm{~mL}$ of $95 \%$ ethanol. Absorbance was recorded at $600 \mathrm{~nm}$.

\section{In vitro plant microbe interaction assay}

On the basis of bacterial screening assays, the most efficient bacteria were further used for plant growth observation under 1 and $2 \%$ of petrol stress on the basis of soil dry weight. Petrol (Gasoline) used for the current study was in the liquid state, colorless to pale brown, molecular weight $108 \mathrm{~g} / \mathrm{mol}$, density $0.7-0.8 \mathrm{~g} / \mathrm{cm}^{3}$ and insoluble in water. 
Maize was used as test plant and the experiment was conducted in March, 2020. Certified seeds (hybrid DK6714, Monsanto, USA) were procured from Punjab Seed Corporation, Lahore, Pakistan and were surface sterilized and inoculated with bacterial cultures after adjusting optical densities at $600 \mathrm{~nm}$ to $\sim 10^{6}-10^{7} \mathrm{CFU} / \mathrm{mL}$ for one $\mathrm{h}$. Seven seeds were sown per pot containing $165 \mathrm{~g}$ of sterilized sieved soil and experiment was done in triplicates for each treatment i.e., control (without petrol stress and bacterial treatment), negative control (with 1 and $2 \%$ petrol stress without bacterial treatment), bacterial treatment (without petrol stress) and bacterial treatment with 1 and $2 \%$ petrol. Petrol treatment was given to soil at seedling stage of maize plants, after three days of germination. Pots were placed in light (10 Klux, $16 \mathrm{~h}$ duration) at $25 \pm 2^{\circ} \mathrm{C}$ and after 24 days of growth period, seedlings were harvested and analyzed for growth attributes i.e., height of plant, fresh weight, root length and leaves number while for biochemical analysis, plants were observed for protein content, auxin content, chlorophyll content, total soluble sugars (TSS), total free amino acids, free proline and glycine betaine content. Protein content was determined following Lowry et al. (1951), $1 \mathrm{~g}$ of crushed plant material was mixed with 4 $\mathrm{mL}$ of phosphate buffer following centrifugation at $10,000 \mathrm{rpm}$. Reaction mixture was prepared by adding $0.4 \mathrm{~mL}$ extract, $2 \mathrm{~mL}$ Folin's mixture $0.2 \mathrm{~mL}$ of Folin's ciocalteu's reagent, then kept at room temperature for 45 min to build out the color and absorbance was taken at 750 $\mathrm{nm}$. Standard curve of bovine serum albumin (BSA) was used to interpret the results.

Auxin content was observed following Mahadevan (1984), for which $0.5 \mathrm{~g}$ plant material was mixed with $1 \mathrm{~mL}$ diethyl ether and kept at $4^{\circ} \mathrm{C}$ for $2-3 \mathrm{~h}$. Extract was again mixed with $0.5 \mathrm{~mL}$ diethyl ether and then $500 \mu \mathrm{L}$ of $5 \%$ sodium hydrogen carbonate was added and shaken well. Bicarbonate layer was acidified with $6 \mathrm{~N} \mathrm{HCl}$ to $\mathrm{pH} 3$. Then, $2 \mathrm{~mL}$ of salkowski reagent was added following incubation in dark for $30 \mathrm{~min}$. Absorbance was read at $535 \mathrm{~nm}$. Standard curve of auxin was used to interpret the results.

Chlorophyll content was determined following Lichtenthaler and Wellburn (1983) for which $1 \mathrm{~g}$ of squeezed plant material was soaked in $10 \mathrm{~mL}$ of $80 \%$ acetone solution following overnight incubation in dark. Absorbance was recorded at 663,646 and $470 \mathrm{~nm}$ to determine the concentrations of chlorophyll 'a', chlorophyll 'b' and carotenoid contents.

Total soluble sugars (TSS) were estimated by phenolsulphuric acid method following Tiwari et al. (2017). Similarly, total free amino acid content was determined following Khanna et al. (2019) for which $0.1 \mathrm{~g}$ plant material was homogenized in $80 \%$ alcohol followed by incubation for fifteen min using water bath. Then, $0.2 \mathrm{~mL}$ supernatant was mixed with $3.8 \mathrm{~mL}$ of ninhydrin reagent and again boiled using water bath. Mixture was allowed to cool till the development of purplish color and absorbance was recorded at $570 \mathrm{~nm}$. Results were inferred by using standard curve of leucine.

Proline content was detected following Karthik et al. (2016). Briefly, $0.5 \mathrm{~g}$ plant material was homogenized in $3 \%$ sulphosalicylic acid. Filtrate was mixed in acid ninhydrin reagent and glacial acetic acid in 1:1:1 which was then heated using water bath at $100^{\circ} \mathrm{C}$ for $1 \mathrm{~h}$ followed by placing on ice bath for twenty min. Further, $1.5 \mathrm{~mL}$ of toluene was added and optical density (OD) was measured at $520 \mathrm{~nm}$. Standard curve of proline was used to interpret the results.

Glycine betaine accumulation was recorded following Sadak et al. (2019). For this, $0.5 \mathrm{~g}$ dried plant sample was homogenized in $5 \mathrm{~mL}$ distilled water containing $0.05 \%$ toluene for $24 \mathrm{~h}$ using shaker. Reaction mixture was prepared by mixing $0.5 \mathrm{~mL}$ filtrate, $1 \mathrm{~mL} 2 \mathrm{~N}$ hydrochloric acid and $0.1 \mathrm{~mL}$ potassium iodide solution. Tubes were chilled, shaken and gently mixed with $2 \mathrm{~mL}$ ice-cold distilled water and then with 1, 2-dichloroethane. Two layers were formed and absorbance of bottom pink layer was recorded at $365 \mathrm{~nm}$. Standard curve of glycine betaine was used for inferring the results.

\section{Statistical analysis}

Three replicates were taken for determining the biosurfactant production potential, EPS production and biofilm formation by the bacterial isolates. Also, for in vitro plant microbe interaction assay twenty four replicates were taken for observing various parameters. The above replicates were used to statistically analyze the data using statistical package, SPSS (version; 16.0). Duncan's multiple range test (post hoc test) was applied to determine the significant differences among means of the treatments at $5 \%$ level of significance $(\mathrm{P}=0.05)$.

\section{Results}

\section{Bacterial profiling for biosurfactant production potential}

Isolates were examined for biosurfactant production potential. Emulsification index test indicated 54.9 \pm 2.6 , $53.8 \pm 2.1, \quad 53.0 \pm 2.7$ and $50.9 \pm 3.1 \%$ emulsification by isolates Enterobacter sp. (A5C), Exiguobacterium sp. (A13G), Enterobacter sp. (A11E) and E. cloacae (A9G) using $n$-hexane as hydrophobic substrate respectively, while data for BATH assay showed that percentage of hydrophobicity of isolates Enterobacter sp. (A5C), E. cloacae (A9G), Exiguobacterium sp. (A13G) and Enterobacter sp. (A11E) with $\mathrm{HC}$ was $64.7 \pm 5.1,56.2 \pm 3.5$, $54.5 \pm 5.1$ and $46.2 \pm 6.6 \%$ respectively (Fig. 1A). Penetration assay revealed that all isolates were positive for this assay showing color change from clear red to cloudy white (Fig. 1B). Positive test considered when silica entered from hydrophobic paste to hydrophilic phase by breaking the barrier of hydrocarbon in between both phases. This is because of production of biosurfactants. Likewise, $\mathrm{HC}$ over 


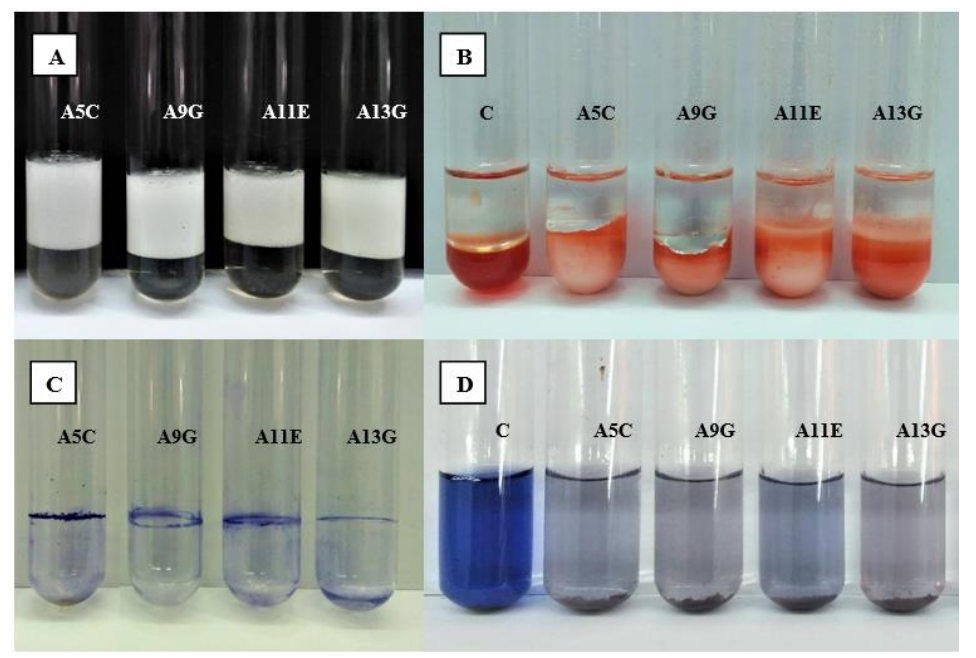

Fig. 1: Emulsification index test (A), penetration assay (B), biofilm production test (C) and hydrocarbon (HC) degradation test using $2 \%$ $n$-hexane $[\mathrm{C}=$ Control, $\mathrm{A} 5 \mathrm{C}=$ Enterobacter $\mathrm{sp} ., \mathrm{A} 11 \mathrm{E}=$ Enterobacter $\mathrm{sp} ., \mathrm{A} 9 \mathrm{G}=$ E. cloacae and $\mathrm{A} 13 \mathrm{G}=$ Exiguobacterium $\mathrm{sp}$. $]$

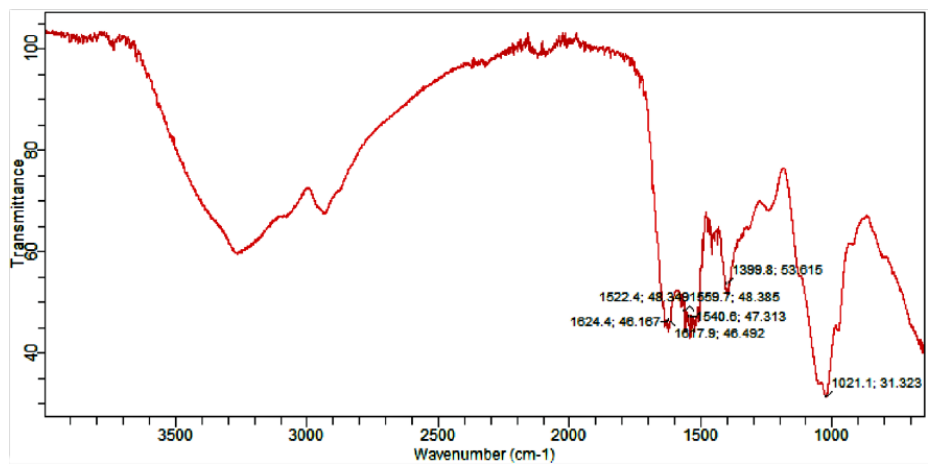

Fig. 2: IR spectra of EPS extracted from Enterobacter sp. (A5C)

lay agar method showed potentiality of isolates to make halo areas around bacterial colonies. Enterobacter sp. (A5C) exhibited clear halo around bacterial colony, while rest of the isolates were poor in making halo zones. Further, HC degradation assay indicated that with $1 \% \mathrm{HC}$, isolates $E$. cloacae (A9G), Exiguobacterium sp. (A13G), Enterobacter sp. (A11E) and Enterobacter sp. (A5C) showed 78.4 \pm 1.8 , $75.7 \pm 2.3,75.5 \pm 1.2$ and $73.0 \pm 1.4 \%$ degradation potential, respectively whereas, $73.8 \pm 2.6,69.6 \pm 0.7,66.8 \pm 1.7$ and $56.5 \pm 3.1 \%$ degradation potential was shown by isolates $E$. cloacae (A9G), Exiguobacterium sp. (A13G), Enterobacter sp. (A5C) and Enterobacter sp. (A11E) respectively with $2 \% \mathrm{HC}$ (Fig. 1D).

\section{Bacterial profiling for EPS detection}

Isolates Enterobacter sp. (A5C) and Enterobacter sp. (A11E) were positive for EPS production. These isolates showed thick slimy colonies (mucoid) and ability of ropiness indicating cohesive and sticky appearance due to presence of EPS while Voges-proskauer test for acetoin production was positive for isolates Enterobacter sp. (A5C),
E. cloacae (A9G) and Enterobacter sp. (A11E). Isolates Enterobacter sp. (A5C) and Enterobacter sp. (A11E) produced 9.27 and $4.13 \mathrm{mg}$ of EPS per $100 \mathrm{~mL}$ of culture. On the basis of these assays, IR spectra was obtained through FTIR for the most efficient EPS producing bacteria i.e., Enterobacter sp. (A5C). IR spectra showed that peak at $1522.4 \mathrm{~cm}^{-1}$ corresponded to strong $\mathrm{N}-\mathrm{O}$ stretching showing nitro compound while peaks at 1624.4 and $1617.9 \mathrm{~cm}^{-1}$ attributed to $\mathrm{C}=\mathrm{C}$ stretching with medium absorption intensity indicating conjugated alkene and strong $\mathrm{C}=\mathrm{C}$ stretching indicating $\alpha, \beta$-unsaturated ketone respectively. Also, absorption at $1540.6 \mathrm{~cm}^{-1}$ was due to stretching vibration of $\mathrm{N}-\mathrm{O}$ group with strong absorption intensity, whereas, peaks at 1399.8 and $1021.1 \mathrm{~cm}^{-1}$ was assigned to $\mathrm{O}-\mathrm{H}$ bending carboxylic acids with medium absorption intensity which is a characteristic of carbohydrate ring and $\mathrm{C}-\mathrm{N}$ stretching cyanide group respectively (Fig. 2).

\section{Bacterial profiling for biofilm production}

All isolates were positive for biofilm production. A visible film layer the wall of test tubes was observed visually while 
Phytostimulatory Potential of Multitrait Petrol Tolerant Bacteria / Intl J Agric Biol, Vol 26, No 2, 2021

(A)

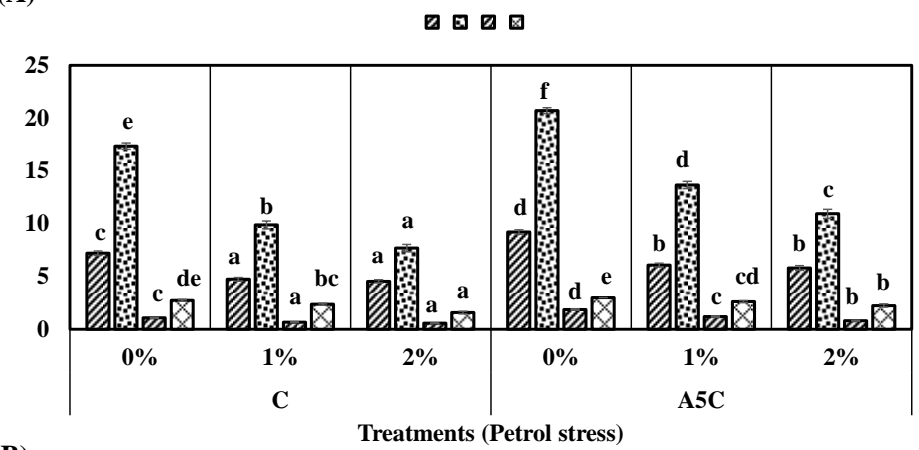

(B)

Treatments (Petrol stress)

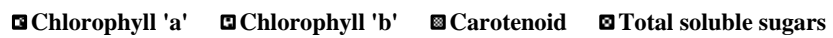

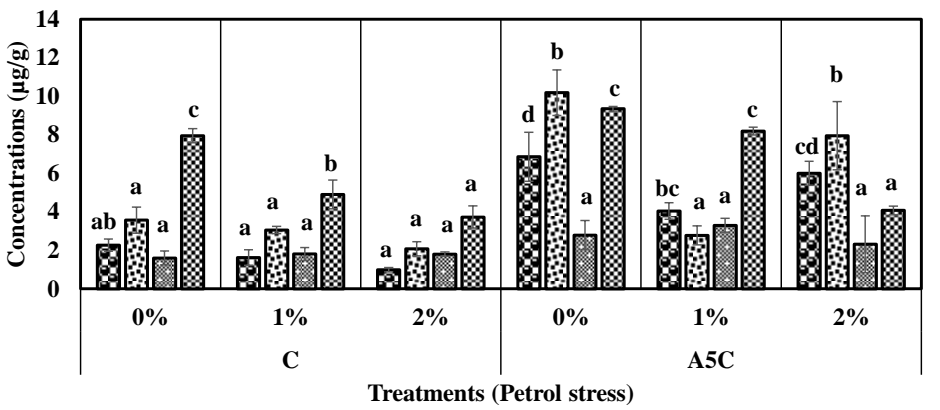

Fig. 3: Effect of bacterial treatment with and without petrol stress $(0,1$ and $2 \%)$ on height of plant, root length, fresh weight and leaves number (A) and chlorophyll 'a', chlorophyll 'b', carotenoid content and total soluble sugars (B) of Zea mays. Data represent mean of twenty four replicates. Different letters indicate significant differences between treatments using Duncan's multiple range test $(P=0.05)$ [Control - C, Bacterial strain: Enterobacter sp. (A5C)]

biofilms was quantified spectrophotometrically (Fig. 1C). It was found that isolates Enterobacter sp. (A5C), Enterobacter sp. (A11E), E. cloacae (A9G) and Exiguobacterium sp. (A13G) exhibited $0.51 \pm 0.05,0.40 \pm 0.03,0.35 \pm 0.04$ and $0.31 \pm 0.04$ absorbance at $600 \mathrm{~nm}$, respectively.

\section{In vitro plant microbe interaction assay}

On the basis of screening profile for biosurfactants, EPS and biofilm production potential, the best isolate i.e., Enterobacter sp. (A5C) was selected for in vitro plant microbe interaction assay. It was found that 28.1, 19.4, 73.0 and $9.0 \%$ increase in height of plant, root length, fresh weight and leaf number was counted respectively, over control when grown without petrol stress. In the presence of $1 \%$ petrol stress, 28.7, 38.3, 80.3 and $10.5 \%$ increment while in the presence of $2 \%$ petrol stress, 28.1, 42.1, 43.0 and $42.1 \%$ increase in height of plant, root length, fresh weight and leaves number was noted respectively, when compared with respective control plants (Fig. 3A).

Among the biochemical attributes, significant increase in protein content was recorded up to $40.7 \%$ in bacterially treated plants without petrol stress, 60.2 and $48.8 \%$ increase in bacterial inoculated plants in the presence of 1 and $2 \%$ petrol stress respectively, over respective control treatments. Similarly, prominent rise in chlorophyll ' $a$ ', chlorophyll ' $b$ ' and carotenoid content of inoculated plants was noted up to $203.0,185.5$ and $74.2 \%$ respectively, over control. Under 1\% petrol stress, 148.4 and $82.3 \%$ increase in chlorophyll ' $a$ ' and carotenoid content while $9.1 \%$ decrease in chlorophyll 'b' content was detected, over respective control. On the contrary, 508.0, 282.1 and 28.3\% increment was observed in chlorophyll 'a', chlorophyll ' $b$ ' and carotenoid content of treated plants, respectively over respective control treatment. Similarly, TSS, free aminoacids, proline and glycine betaine tended to increase upto $17.6,96.1,51.5$ and $9.0 \%$ respectively over control, when plants were grown without petrol stress. On the contrary, under $1 \%$ petrol stress, TSS, total free aminoacids, proline and glycine betaine contents were increased up to $67.2,113.0,97.4$ and $16.1 \%$ while under $2 \%$ petrol stress, 9.1, 113.2, 87.2 and $3.54 \%$ increment was recorded in bacterially treated plants respectively, over respective control plants (Fig. 3B and 4).

\section{Discussion}

The present study signifies plant-bacterial partnership by secreting biosurfactants, EPS and biofilms to remediate petrol contamination from the rhizosphere of maize plants. 

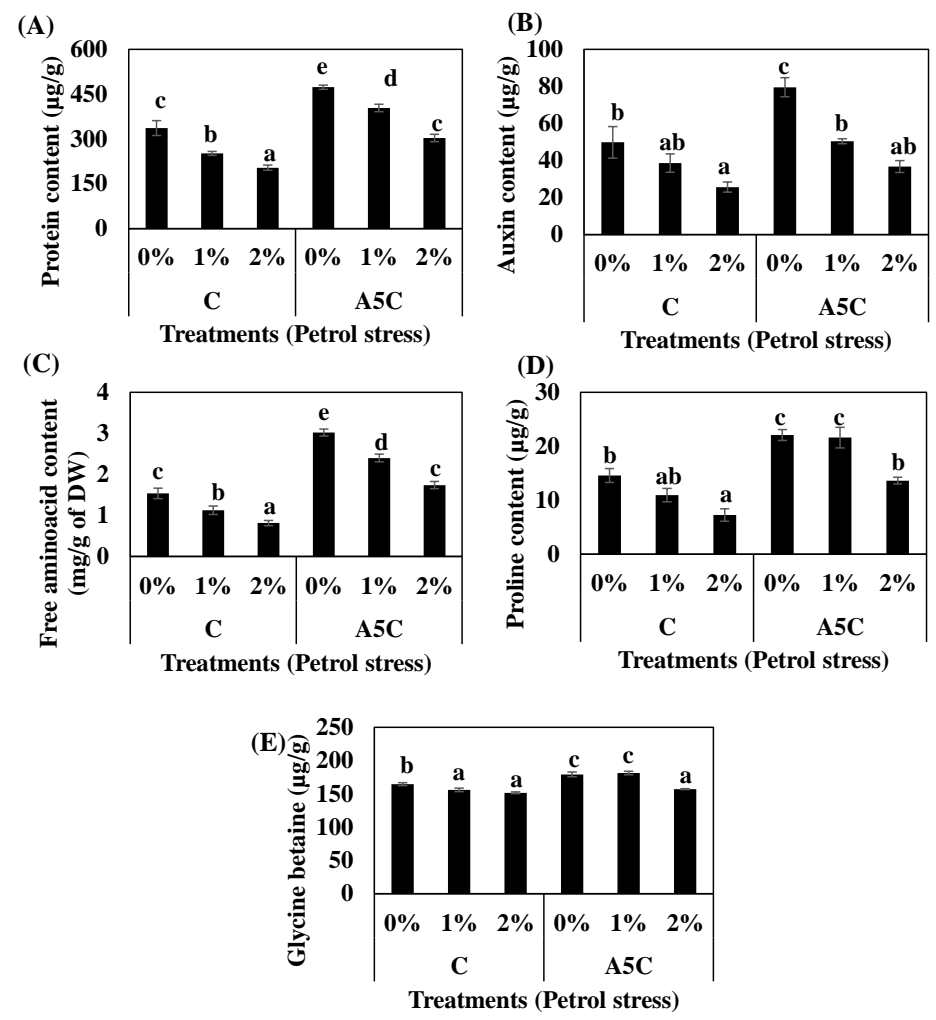

Fig. 4: Effect of bacterial treatment with and without petrol stress $(0,1$ and $2 \%)$ on protein content (A), auxin content (B), free aminoacid content (C), proline (D) and glycine betaine content (E) of Zea mays. Data represent mean of twenty four replicates. Different letters indicate significant differences between treatments using Duncan's multiple range test $(\mathrm{P}=0.05)$ [Control $-\mathrm{C}$, Bacterial strain: Enterobacter sp. (A5C)]

Screening profile of bacterial strains provided collective data of the most efficient biosurfactant and EPS producing as well as biofilm making bacterial strain i.e., Enterobacter sp. (A5C), for its surviving potential in petrol contaminated soil and bacterial-assisted plant microbe interaction. Screening results in this study suggested the ability of selected bacteria to enhance bioavailability of hydrocarbons to bacterial cells as they ultimately enhanced the rate of biodegradation and consumption of HC. These characteristics of bacteria were verified in the studies of Joy et al. (2017) and Ashitha et al. (2020).

On the other side, EPS and biofilm synthesizing ability was also checked to analyze bacterial behavior towards surface adhesions or colonizing potential with plant roots. FTIR analysis was made to determine the functional groups that exclusively confirmed the presence of alcoholic and carboxylic groups in extracted EPS. Kumar et al. (2011) have reported the presence of polysaccharide group in the EPS extracted from biofilm forming bacteria via FTIR analysis. Also, Qurashi and Sabri (2012) studied biofilm formation and EPS accumulation by salt-tolerant bacteria i.e., Halomonas variabilis (HT1) and Planococcus rifietoensis (RT4) and observed plant (Cicer arietinum) growth enhancement and improved soil aggregation through these bacterial application. In addition, Mostefaoui et al. (2014) screened thirty EPS producing bacterial strains on the basis of mucilaginous colony. Our data is in excellent agreement of all the above mentioned studies.

Enterobacter sp. (A5C) was further used in in vitro plant-microbe interaction assay due to its potential for biosurfactants, EPS and biofilms production. Significant increase in growth and biochemical parameters was observed in bacterially inoculated plants when grown without and with 1 and $2 \%$ of petrol stress (Fig. 5). This increase in physiological and biochemical attributes of maize plants might be due to the bacterial ability to produce biosurfactants that accumulate at soil-petrol interface due to its amphiphilic nature.

Khanna et al. (2019) reported increased level of secondary metabolites, proline, total soluble sugars, free amino acid and glycine betaine content in Solanum lycopersicum grown under cadmium stress using Pseudomonas aeruginosa and Burkholderia gladioli strains. Also, Sadak et al. (2019) conducted a study that highlighted the increased level of biochemical parameters in Chenopodium quinoa plants when foliar application of trehalose was used. Similarly, Habib et al. (2019) have also reported a significant increase in protein and chlorophyll 


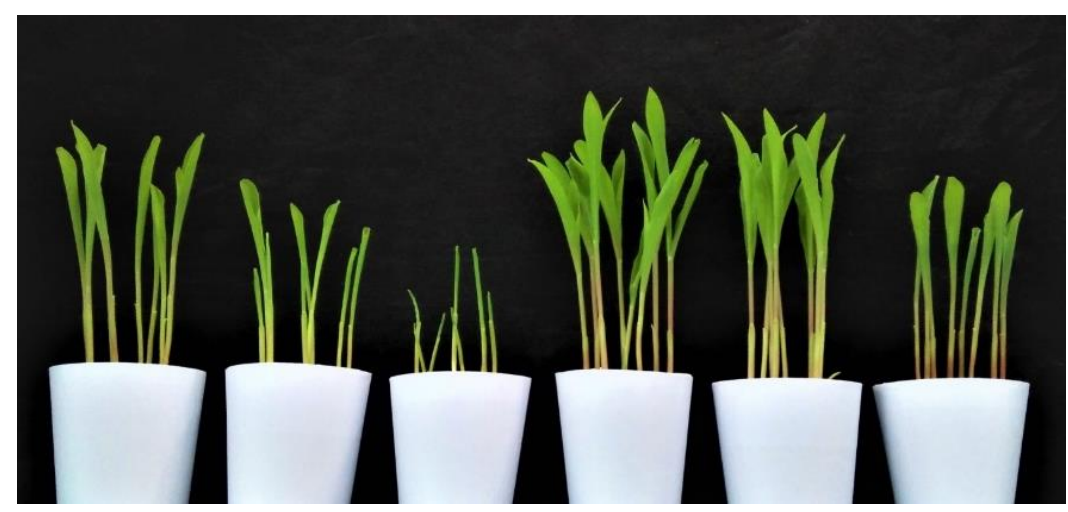

Fig. 5: Effect of Enterobacter sp. (A5C) inoculation on the growth of maize with and without petrol stress $(0,1$ and $2 \%)$ [A =noninoculated control without bacterial treatment, $\mathrm{B}=$ non-inoculated control with $1 \%$ petrol stress, $\mathrm{C}=$ non-inoculated control with $2 \%$ petrol stress, D = bacterial treatment Enterobacter sp. (A5C), E = bacterial treatment Enterobacter sp. $(\mathrm{A} 5 \mathrm{C})+1 \%$ petrol stress and $\mathrm{F}=$ bacterial treatment Enterobacter sp. (A5C) $+2 \%$ petrol stress]

content under chromium stress using bacterial application. Similarly, Naseem and Bano (2014) conducted a study in which they selected Proteus penneri (Pp1), P. aeruginosa (Pa2), and Alcaligenes faecalis (AF3) strains as EPSproducing bacteria on the basis of mucoid appearance of colonies. Authors observed tremendous increase in plant biomass production, root and shoot lengths, TSS, protein and proline content of bacterially treated maize plants under drought stress conditions. Increase in all studied parameters even in the presence of petrol might be due to the fact that isolate Enterobacter sp. (A5C) which was auxin-producing, biosurfactant and EPS producing and also possessed biofilm making ability, might have initiated biofilms on plant roots by secreting EPS. It might be possible that these biofilms colonized the roots and by synthesizing auxin and biosurfactants, it would have stimulated plant growth in the presence of petrol stress. Thus, nutrient uptake, solubilization of minerals and protection from toxins or petrol pollutants made the bacterially treated plants able to grow well in that petrol stressed conditions.

\section{Conclusion}

Present study revealed the multitrait potential of auxin producing Enterobacter sp. (A5C) as biosurfactant production vis-à-vis EPS and biofilm synthesizing ability. The bacterial treatments have shown significant improvement in growth and biochemical attributes of treated maize plants under petrol stress owing to the presence of above mentioned multitrait potential. It may be concluded that bacteria might have produced extracellular polymeric substances (EPS) that constructed biofilm matrix, which ultimately promoted root colonization that has been effective in growth enhancement due to improved nutrient uptake and water absorption. The same explanation was also reported by Qurashi and Sabri (2012) who worked on biofilm producing bacteria under salt stress.

\section{Acknowledgements}

This work was supported by University of the Punjab, Lahore 54590, Pakistan.

\section{Author Contributions}

Both authors contributed to the study conception and design. AA conceived and designed the research study. Material preparation, data collection and analysis were performed by $\mathrm{SH}$. The first draft of the manuscript was written by SH. AA commented on previous versions of the manuscript, read and approved the final manuscript.

\section{Conflict of Interest}

Authors declare no conflict of interests to disclose.

\section{Data Availability}

Data presented in this study will be available on a fair request to the corresponding author.

\section{Ethics Approval}

Not applicable in this paper.

\section{References}

Ahmed A, S Hasnain (2020). Extraction and evaluation of indole acetic acid from indigenous auxin-producing rhizosphere bacteria. J Anim Plant Sci 30:1024-1036

Ashitha A, EK Radhakrishnan, M Jyothis (2020). Characterization of biosurfactant produced by the endophyte Burkholderia sp. WYAT7 and evaluation of its antibacterial and antibiofilm potentials. $J$ Biotechnol 313:1-10

Escárcega-González CE, JA Garza-Cervantes, A Vázquez-Rodríguez, JR Morones-Ramírez (2018). Bacterial exopolysaccharides as reducing and/or stabilizing agents during synthesis of metal nanoparticles with biomedical applications. Intl J Polym Sci 2018; Article 7045852 
Gull A, AA Lone, NI Wani (2019). Biotic and abiotic stresses in plants. In: Abiotic and Biotic Stress in Plants, pp:1-19. Alexandre Bosco de Oliveira, IntechOpen, London, UK

Habib S, H Fatima, A Ahmed (2019). Comparative analysis of pregermination and post-germination inoculation treatments of $\mathrm{Zea}$ mays $\mathrm{L}$. to mitigate chromium toxicity in $\mathrm{Cr}$-contaminated soils. Pol J Environ Stud 28:597-607

Habib S, Johari WLW, Shukor MY, Yasid NA (2017). Screening of hydrocarbon-degrading bacterial isolates using the redox application of 2, 6-DCPIP. Bioremediat Sci Technol Res 5:13-16

Joy S, PK Rahman, S Sharma (2017). Biosurfactant production and concomitant hydrocarbon degradation potentials of bacteria isolated from extreme and hydrocarbon contaminated environments. Chem Eng J 317:232-241

Karthik C, M Ove, R Thangabalu, R Sharma, SB Santhosh, PI Arulselvi (2016). Cellulosimicrobium funkei-like enhances the growth of Phaseolus vulgaris by modulating oxidative damage under Chromium (VI) toxicity. J Adv Res 7:839-850

Khanna K, VL Jamwal, A Sharma, SG Gandhi, P Ohri, R Bhardwaj, AA Al-Huqail, MH Siddiqui, HM Ali, P Ahmad (2019). Supplementation with plant growth promoting rhizobacteria (PGPR) alleviates cadmium toxicity in Solanum lycopersicum by modulating the expression of secondary metabolites. Chemosphere 230:628-639

Kırmusaoğlu S (2019). Antimicrobials, antibiotic resistance, antibiofilm strategies and activity methods. In: The Methods for Detection of Biofilm and Screening Antibiofilm Activity of Agents, p:99. Kirmusaoğlu S (ed). IntechOpen, London, UK

Kumar MA, KTK Anandapandian, K Parthiban (2011). Production and characterization of exopolysaccharides (EPS) from biofilm forming marine bacterium. Braz Arch Biol Technol 54:259-265

Lichtenthaler HK, AR Wellburn (1983). Determinations of total carotenoids and chlorophylls $\mathrm{a}$ and $\mathrm{b}$ of leaf extracts in different solvents Biochem Soc Trans 11:591-592

Lowry OH, NJ Resebrough, AL Farr (1951). Protein measurement with the folin-phenol reagent. J Biol Chem 193:265-275

Mahadevan A (1984). In: Growth Regulators, Microorganisms and diseased plants. Oxford and IBH Publishing Company, India

Mostefaoui A, A Hakem, B Yabrir, S Boutaiba, A Badis (2014). Screening for exopolysaccharide-producing strains of thermophilic lactic acid bacteria isolated from Algerian raw camel milk. Afr J Microbiol Res 8:2208-2214
Mu'minah, Baharuddin, H Subair, Fahruddin, B Darwisah (2015). Isolation and screening of exopolysaccharide producing bacterial (EPS) from potato rhizosphere for soil aggregation. Intl J Curr Microbiol Appl Sci 4:341-349

Naseem H, A Bano (2014). Role of plant growth-promoting rhizobacteria and their exopolysaccharide in drought tolerance of maize. $J$ Plant Interact 9:689-701

Nishanthi R, S Kumaran, P Palani, C Chellaram, TP Anand, V Kannan (2010). Screening of biosurfactants from hydrocarbon degrading bacteria. J Ecobiotechnol 2:47-53

Pendse A, K Aruna (2018). Use of various screening methods for isolation of potential biosurfactant producing microorganism from oilcontaminated soil sample. J Pharm Res 12:599-605

Qurashi AW, AN Sabri (2012). Bacterial exopolysaccharide and biofilm formation stimulate chickpea growth and soil aggregation under salt stress. Braz J Microbiol 43:1183-1191

Sadak MS, HMS El-Bassiouny, MG Dawood (2019). Role of trehalose on antioxidant defense system and some osmolytes of quinoa plants under water deficit. Bull Natl Res Cent 43; Article 5

Shoeb E, N Ahmed, J Akhter, U Badar, K Siddiqui, F Ansari, M Waqar, S Imtiaz, N Akhtar, QU Shaikh, R Baig (2015). Screening and characterization of biosurfactant-producing bacteria isolated from the Arabian Sea coast of Karachi. Turk J Biol 39:210-216

Thavasi R, S Sharma, S Jayalakshmi (2011) Evaluation of screening methods for the isolation of biosurfactant producing marine bacteria. $J$ Pet Environ Biotechnol 1:1-6

Tiwari S, V Prasad, PS Chauhan, C Lata (2017). Bacillus amyloliquefaciens confers tolerance to various abiotic stresses and modulates plan response to phytohormones through osmoprotection and gene expression regulation in rice. Front Plant Sci 8; Article 1510

Walter V, C Syldatk, R Hausmann (2010). Screening concepts for the isolation of biosurfactant producing microorganisms. In: Biosurfactants. Advances in Experimental Medicine and Biology, Vol. 672, pp:1-13. Sen R (ed). Springer, New York, USA

Welman AD, IS Maddox (2003). Exopolysaccharides from lactic acid bacteria: Perspectives and challenges. Trends in Biotechnol 21:269274

Xia M, R Chakraborty, N Terry, RP Singh, D Fu (2020). Promotion of saltgrass growth in a saline petroleum hydrocarbons contaminated soil using a plant growth promoting bacterial consortium. Intl Biodeterior Biodegradation 146; Article 104808 